\title{
ANALISIS UNSUR TOKSIK DAN MAKRO-MIKRO NUTRIEN DALAM BAHAN MAKANAN DENGAN METODE ANALISIS AKTIVASI NEUTRON
}

\author{
Th. Rina Mulyaningsih, Istanto, Saeful Yusuf, Siti Suprapti \\ Pusat Teknologi Bahan Industri Nuklir BATAN \\ Kawasan Puspiptek Serpong, Tangerang 15310 \\ e-mail : thrina2005@yahoo.com
}

Diterima 7 Januari 2010, diterima dalam bentuk perbaikan 15 Januari 2010, disetujui 18 Januari 2010

\begin{abstract}
ABSTRAK
ANALISIS UNSUR TOKSIK DAN MAKRO-MIKRO NUTRIEN DALAM BAHAN MAKANAN DENGAN METODE ANALISIS AKTIVASI NEUTRON. Telah dilakukan penentuan kadar unsur toksik dan makro-mikro nutrien dalam bahan makanan dengan menggunakan metode analisis aktivasi neutron (AAN). Jenis cuplikan bahan makanan yang diteliti meliputi sayuran, kacang-kacangan, bumbu dan rempah, tepung, daging dan ikan. Cuplikan dikumpulkan dari pasar Serpong. Hasil analisis menunjukkan bahwa cuplikan bahan makanan mengandung makro nutrien dengan kadar > $1000 \mathrm{mg} / \mathrm{kg}$, seperti : K, Ca, Mg, Na dan Cl, mikronutrien dengan kadar antara 10 hingga < $1000 \mathrm{mg} / \mathrm{kg}$ : Fe, $\mathrm{Mn}, \mathrm{Zn}, \mathrm{Se}, \mathrm{Br}, \mathrm{Rb}$, dan $\mathrm{La}$, dan unsur toksik $\mathrm{Co}, \mathrm{Sb}, \mathrm{Hg}$, As dan $\mathrm{Cr}$ dengan kadar kurang dari $5 \mathrm{mg} / \mathrm{kg}$. Konsentrasi As dalam ikan, beras dan $\mathrm{Hg}$ dalam cabai merah dan ikan telah melebihi baku mutu yang ditetapkan pemerintah. Konsentrasi Zn dalam beberapa cuplikan, telah melebihi nilai baku mutu. Batasan nilai ini perlu dipertimbangkan, mengingat rata-rata asupan harian Zn masih di bawah nilai yang direkomendasikan yaitu 15 mg/hari. Kekurangan unsur ini dapat mengganggu pertumbuhan dan metabolisme tubuh. Kadar Al dalam bahan makanan cukup tinggi antara 10 - $500 \mathrm{mg} / \mathrm{kg}$, logam Al termasuk logam ringan yang bersifat toksik, sehingga keberadaannya perlu mendapat perhatian. Evaluasi unsur-unsur dibandingkan terhadap nilai kecukupan kebutuhan harian RDA (Recommended Daily Acceptable). Dalam studi ini dijelaskan juga efek apabila kekurangan atau kelebihan asupan unsur tersebut bagi kesehatan.
\end{abstract}

Kata kunci : makro-mikro nutrien, unsur toksik, bahan makanan, aktivasi neutron

\begin{abstract}
ANALYSIS OF TOXIC ELEMENTS AND MACRO-MICRO NUTRIENTS IN FOOD STUFF BY USING NEUTRON ACTIVATION ANALYSIS. Determination of toxic elements and macro-micro nutrient in food stuff by neutron activation analysis (NAA) has been done. The kinds of samples are vegetables, legume, mace and flavor, flour, fish and flesh. Samples had been collected from market in Serpong. Analysis of the samples show macro nutrients with concentration >1000 mg/kg, as K, Ca, Mg, Na, and Cl; micronutrients with concentration $10-100 \mathrm{mg} / \mathrm{kg}: \mathrm{Fe}, \mathrm{Mn}, \mathrm{Zn}$, $\mathrm{Se}, \mathrm{Br}, \mathrm{Rb}$, and $\mathrm{La}$; and toxic elements with concentration below $5 \mathrm{mg} / \mathrm{kg}$ as $\mathrm{Co}, \mathrm{Sb}, \mathrm{Hg}$, As and $\mathrm{Cr}$. As concentration in fish and rice and $\mathrm{Hg}$ concentration in fish and red chili is exceed from government permission value. Zinc concentration in some kind of samples is more than permission value, but it should be considered because of its average daily intake is lower then recommended value $15 \mathrm{mg} /$ day. The $\mathrm{Zn}$ deficiencies can disturb growth and metabolism. Al concentration in samples is high enough $10-500 \mathrm{mg} / \mathrm{kg}$; it must be take into account serious attention because of its toxicity. Evaluation of these elements is compared to sufficiency value of daily requirement RDA (Recommended Daily Acceptable). In this study was discussed potential hazards for human while its deficiencies or excessive intake.
\end{abstract}

Key words: macro-micro nutrients, toxic elements, foodstuff, neutron activation

\section{PENDAHULUAN}

Thenter ubuh manusia membutuhkan unsur esensial dalam jumlah makro seperti $\mathrm{Ca}, \mathrm{P}, \mathrm{K}, \mathrm{S}, \mathrm{Na}, \mathrm{Cl}$ dan $\mathrm{Mg}$, maupun mikro seperti Fe, I, Cu, Zn, Mn, Se dan Co. Di samping itu ada beberapa unsur mikro (logam non esensial) yang merupakan kelompok logam berat yang tidak mempunyai fungsi biologik bagi tubuh, bahkan sangat berbahaya karena dapat menyebabkan keracunan (toksisitas), yaitu $\mathrm{Pb}, \mathrm{Hg}, \mathrm{As}, \mathrm{Cd}$ dan Al (logam ringan). Pengaruh negatif yang disebabkan diet logam tidak selalu oleh logam nonesensial saja, logam 
esensialpun dapat memberi efek negatif bila asupan kurang dari kebutuhan atau akan bersifat toksik bila asupan dalam jumlah berlebih ${ }^{[1]}$.

Kontaminasi bahan makanan yang berasal dari produk pertanian dapat terjadi karena pemupukan, pemakaian pestisida maupun karena tanaman tersebut ditanam pada areal yang kondisinya sudah tercemar. Pencemaran ini dapat berasal dari buangan rumah tangga, industri maupun transportasi. Demikian juga kontaminasi pada produk peternakan dan perikanan juga dapat terjadi karena lingkungan yang tercemar, sehingga akan memberikan dampak negatif pada manusia melalui rantai pangan. Dari penelitian yang telah dilakukan, bermacam-macam bahan makanan baik sayuran, buah-buahan, maupun makanan pokok seperti beras yang ada di Indonesia ternyata masih banyak mengandung bahan berbahaya seperti residu pestisida ${ }^{[2]}$.

Beberapa penelitian penentuan unsur makro dan mikro dalam bahan makanan telah dilakukan, di antaranya dapat ditentukan kadar unsur Mg : 303,32 - $1325 \mathrm{mg} / \mathrm{kg}, \mathrm{K}: 2044,6$ - 5511,7 mg/kg, Ca : 464,3 -1082 $\mathrm{mg} / \mathrm{kg}$, dan Zn : 8,52 - 39,80 mg/kg dalam cuplikan porsi makanan siap santap ${ }^{[3]}$; kuantifikasi unsur K, Br, La, Sc dan $\mathrm{Rb}$ dalam cuplikan teh ${ }^{[4]}$, dan kuantifikasi 20 unsur kelumit dalam minuman sachet ${ }^{[5]}$.

Informasi kadar unsur makro dan mikro dalam bahan makanan sangat penting diketahui. Informasi ini digunakan untuk memperkirakan asupan harian dalam tubuh, dengan mempertimbangkan fungsi unsur esensial, nilai RDA (Recomended Daily Acceptable), akibat yang mungkin timbul karena ketidakseimbangan logam esensial dalam tubuh bagi kesehatan dan keamanan pangan. Dengan dasar pertimbangan tersebut, maka telah dilakukan penentuan unsur esensial dan toksik dalam cuplikan bahan makanan terkait dengan lingkungan dan kesehatan. Diharapkan dari kegiatan ini dapat diperoleh informasi kadar unsur makro dan mikro dalam cuplikan bahan makanan yang biasa dikonsumsi dan yang diambil dari areal industri.

Konsentrasi logam toksik maupun esensial dalam bahan makanan jumlahnya sangat rendah, dalam orde $\mathrm{ng} / \mathrm{kg} \mathrm{s.d.} \mathrm{mg} / \mathrm{kg}$. Untuk kuantifikasi kandungan unsur-unsur dalam jumlah kecil, dituntut adanya teknik atau metode analisis dengan sensitivitas tinggi dan bebas dari perlakuan yang potensial menjadi sumber terjadinya kontaminasi pada cuplikan. Metode analisis aktivasi neutron instrumental merupakan metode yang tepat untuk keperluan ini. Teknik nuklir ini mempunyai keunggulan antara lain tidak memerlukan perlakuan kimia terlebih dahulu, mempunyai kemampuan untuk penentuan unsur secara serempak (multiunsur), sensitivitas dan selektivitas yang bisa diandalkan.

\section{METODOLOGI}

\section{Pengambilan cuplikan bahan makanan}

Jenis bahan makanan yang dicuplik meliputi sayuran, beras dan tepung, kacang-kacangan, rempahrempah/bumbu dapur, ikan, dan daging. Pengambilan sampel dilakukan satu kali. Cuplikan bahan pangan ini dikumpulkan dari pasar tradisionil di Serpong.

\section{Preparasi cuplikan}

1. Cuplikan sayuran seperti wortel, tomat, bayam, kangkung, kembang kol dan jenis lainnya yang telah dikumpulkan dicuci dengan air yang mengalir kemudian dibilas dengan aquadest, dipotong kecil-kecil dan dikeringkan dengan teknik pengeringan dingin (freeze dryer), sehingga unsur-unsur yang bersifat mudah menguap, seperti $\mathrm{Hg}$, As dan $\mathrm{Sb}$, dapat dijaga agar tidak hilang selama proses pengeringan berlangsung. Cuplikan ikan dan daging dicuci dan dihancurkan hingga halus dengan pisau stainless, lalu dikeringkan dengan teknik pengeringan dingin. Bumbu seperti bawang merah, bawang putih, lengkuas, dan kunyit dikupas sebelum dicuci, dipotong-potong kecil dan dikeringkan dengan freeze dryer. Cuplikan yang sudah kering digerus hingga halus.

2. Cuplikan biji-bijian dan kacang-kacangan karena dikumpulkan sudah dalam keadaan kering langsung ditumbuk hingga butiran halus. Cuplikan ditumbuk dan disaring untuk mendapatkan butiran lolos 50 - 100 mesh. Sejumlah cuplikan 50 -150 mg ditimbang dengan tepat dalam vial polietilen yang telah dibersihkan. Vial kemudian di seal dan diberi label dan disusun di dalam kapsul iradiasi bersama-sama dengan pemantau fluks dan SRM (Standard Reference Material).

\section{Preparasi SRM}


Analisis Unsur Toksik dan Makro-Mikro Nutrien Dalam Bahan Makanan Dengan Metode Analisis Aktivasi Neutron (Th. Rina Mulyaningsih, dkk..)

Kontrol kualitas hasil analisis secara internal dilakukan dengan menggunakan sejumlah SRM yang memiliki matriks sejenis dengan cuplikan yang akan ditentukan kandungan unsurnya. Sejumlah 50 - $150 \mathrm{mg}$ SRM dengan matriks biologi (tomato leaves, rice flour, wheat flour, bovine liver dan peach leaves) ditimbang dengan tepat dalam vial polietilen. Sebagai pemantau fluks digunakan paduan Al-0,1\% Au (IRRM 530R) yang ditempatkan pada setiap layer target dalam kapsul rabbit.

\section{Iradiasi dan akuisisi data}

Target, yaitu cuplikan yang telah disiapkan dalam kapsul rabbit, diiradiasi di fasilitas iradiasi sistem rabbit reaktor GA. Siwabessy pada fluks neutron termal sekitar $10^{13} \mathrm{n} \cdot \mathrm{cm}^{-2} \cdot \mathrm{s}^{-1}$. Waktu iradiasi bervariasi tergantung waktu paruh dari unsur yang akan dianalisis, seperti yang tertera dalam Tabel 1.

Tabel 1. Kondisi eksperimen dengan metode $\mathrm{k}_{0}-\mathrm{AANI}$ dan AANI komparatif

\begin{tabular}{|l|c|c|c|l|}
\hline $\begin{array}{c}\text { Lokasi } \\
\text { Iradiasi }\end{array}$ & $\begin{array}{c}\text { Waktu } \\
\text { iradiasi }\end{array}$ & $\begin{array}{c}\text { Waktu } \\
\text { pendinginan }\end{array}$ & $\begin{array}{c}\text { Waktu } \\
\text { Pencacahan }\end{array}$ & \multicolumn{1}{c|}{ Unsur yang ditentukan } \\
\hline RS 1 & 1 menit & & 120 detik & $\mathrm{Mn}, \mathrm{Na}, \mathrm{Al}, \mathrm{Mg}, \mathrm{Cl}, \mathrm{Ca}$ \\
\hline $\mathrm{RS} 2,3$ & 5 menit & $1-2$ hari & $1200-1800$ detik & $\mathrm{La}, \mathrm{As}, \mathrm{K}, \mathrm{Na}, \mathrm{Sb}$ \\
\hline $\mathrm{RS} 2,3,4$ & 60 menit & $7-14$ hari & 3600 detik & $\mathrm{Sc}, \mathrm{Cr}, \mathrm{Co}, \mathrm{Fe}, \mathrm{Zn}, \mathrm{Rb}, \mathrm{Hg}, \mathrm{Cs}, \mathrm{Se}, \mathrm{Th}, \mathrm{U}$ \\
\hline
\end{tabular}

Sinar gamma yang dipancarkan oleh radionuklida hasil aktivasi dideteksi oleh detektor HPGe resolusi tinggi yang dirangkai dengan penganalisis puncak multisaluran.

\section{Analisis kuantitatif}

Spektrum-y hasil pencacahan selanjutnya dianalisis dengan perangkat lunak GENIE 2000. Kuantifikasi unsur-unsur dengan waktu paruh panjang dan medium, baik dalam SRM maupun cuplikan dilakukan dengan metode $k_{0}$ menggunakan perangkat lunak $k_{0}$ - IAEA, sedangkan analisis unsur dengan waktu paruh pendek dilakukan secara komparatif, dengan membandingkan terhadap SRM. Dalam perhitungan digunakan parameter reaktor $\alpha=0,03, \Phi=2,7 \times 10^{17} \mathrm{n} \cdot \mathrm{cm}^{-2} \cdot \mathrm{s}^{-1}$ dan nilai $\mathrm{f}=40$.

\section{HASIL DAN PEMBAHASAN}

Untuk menentukan kualitas hasil analisis, sebagaimana yang direkomendasikan oleh IAEA telah digunakan bahan acuan standar ${ }^{[6]}$. Pada penelitian ini digunakan bahan acuan standar matriks biologi SRM NIST 1547 Peach Leaves, SRM NIST 1573a Tomato leaves, SRM NIST 8435 Whole milk, dan SRM NIST 1577b Bovine Liver.

Tabel 2. Kontrol kualitas hasil analisis SRM matriks biologi dengan metode $\mathrm{k}_{0} \mathrm{AANI}$

\begin{tabular}{|l|c|c|c|l|}
\hline Unsur & $\begin{array}{c}\text { Hasil } \\
{\left[\mathbf{m g}_{\mathbf{k g}}{ }^{-1}\right]}\end{array}$ & $\begin{array}{c}\text { Sertifikat } \\
{\left[\mathbf{m g}^{-k^{-1}}\right]}\end{array}$ & $\begin{array}{c}\text { Nilai relatif } \\
\text { bias[\%] }\end{array}$ & \multicolumn{1}{|c|}{ SRM } \\
\hline $\mathrm{Na}$ & $134 \pm 5$ & $136 \pm 4$ & 1,5 & NIST 1573a Tomato leaves \\
\hline $\mathrm{Mn}$ & $87,4 \pm 4,4$ & $98 \pm 3$ & 10,8 & NIST 1547 Peach leaves \\
\hline $\mathrm{La}$ & $2,28 \pm 0,17$ & 2,3 & 0,9 & NIST 1573a Tomato leaves \\
\hline $\mathrm{K}$ & $13,720 \pm 617$ & $13,630 \pm 470$ & 0,7 & NIST 8435 Whole Milk \\
\hline $\mathrm{Br}$ & $11,06 \pm 0,98$ & 11,0 & 0,6 & NIST 1547 Peach leaves \\
\hline $\mathrm{As}$ & $0,115 \pm 0,005$ & $0,112 \pm 0,004$ & 2,7 & NIST 1573a Tomato leaves \\
\hline $\mathrm{Fe}$ & $357 \pm 24$ & $368 \pm 7$ & 3,0 & NIST 1573a Tomato leaves \\
\hline $\mathrm{Rb}$ & $14,56 \pm 1,05$ & $14,89 \pm 0,27$ & 2,2 & NIST 1573a Tomato leaves \\
\hline $\mathrm{Sr}$ & $83,40 \pm 6,67$ & 85 & 2,3 & NIST 1573a Tomato leaves \\
\hline $\mathrm{Sc}$ & $0,1 \pm 0,01$ & 0,1 & 0 & NIST 1573a Tomato leaves \\
\hline $\mathrm{Co}$ & $0,64 \pm 0,03$ & $0,57 \pm 0,02$ & 12,3 & NIST 1573a Tomato leaves \\
\hline $\mathrm{Sb}$ & $0,069 \pm 0,007$ & $0,063 \pm 0,006$ & 9,5 & NIST 1573a Tomato leaves \\
\hline $\mathrm{Ca}$ & $52,810 \pm 1901$ & $50,500 \pm 900$ & 4,6 & NIST 1573a Tomato leaves \\
\hline $\mathrm{Zn}$ & $124 \pm 27$ & $127 \pm 16$ & 2,4 & NIST1577b Bovine liver \\
\hline
\end{tabular}


Tabel 2, menunjukkan hasil analisis unsur dalam sejumlah bahan acuan standar yang digunakan sebagai kontrol kualitas hasil analisis yang meliputi $\mathrm{Na}, \mathrm{Mn}, \mathrm{La}, \mathrm{K}, \mathrm{Br}, \mathrm{As}, \mathrm{Fe}, \mathrm{Rb}, \mathrm{Sr}, \mathrm{Sc}, \mathrm{Co}, \mathrm{Sb}, \mathrm{Ca}$, dan $\mathrm{Zn}$. Hampir keseluruhan hasil analisis yang diperoleh mendekati nilai yang direkomendasikan pada sertifikat. Nilai bias relatif, dibawah $10 \%$, kecuali pada analisis Co (12,3\%).

Contoh profil spektrum-y cuplikan bahan pangan (ikan tongkol), ditampilkan pada Gambar 1. Spektrum-y adalah spesifik untuk sebagian besar cuplikan biologi, yaitu ditandai dengan tingginya Compton plateau pada daerah energi di bawah $500 \mathrm{keV}$. Dari spektrum- $\gamma$ hasil pencacahan dapat diidentifikasi unsur-unsur esensial maupun toksik yang terkandung di dalam cuplikan ikan, yaitu $\mathrm{Se}, \mathrm{Br}, \mathrm{Cr}, \mathrm{Rb}, \mathrm{Cs}, \mathrm{Ag}, \mathrm{Fe}, \mathrm{Zn}, \mathrm{Co}, \mathrm{K}$, La, dan Na.

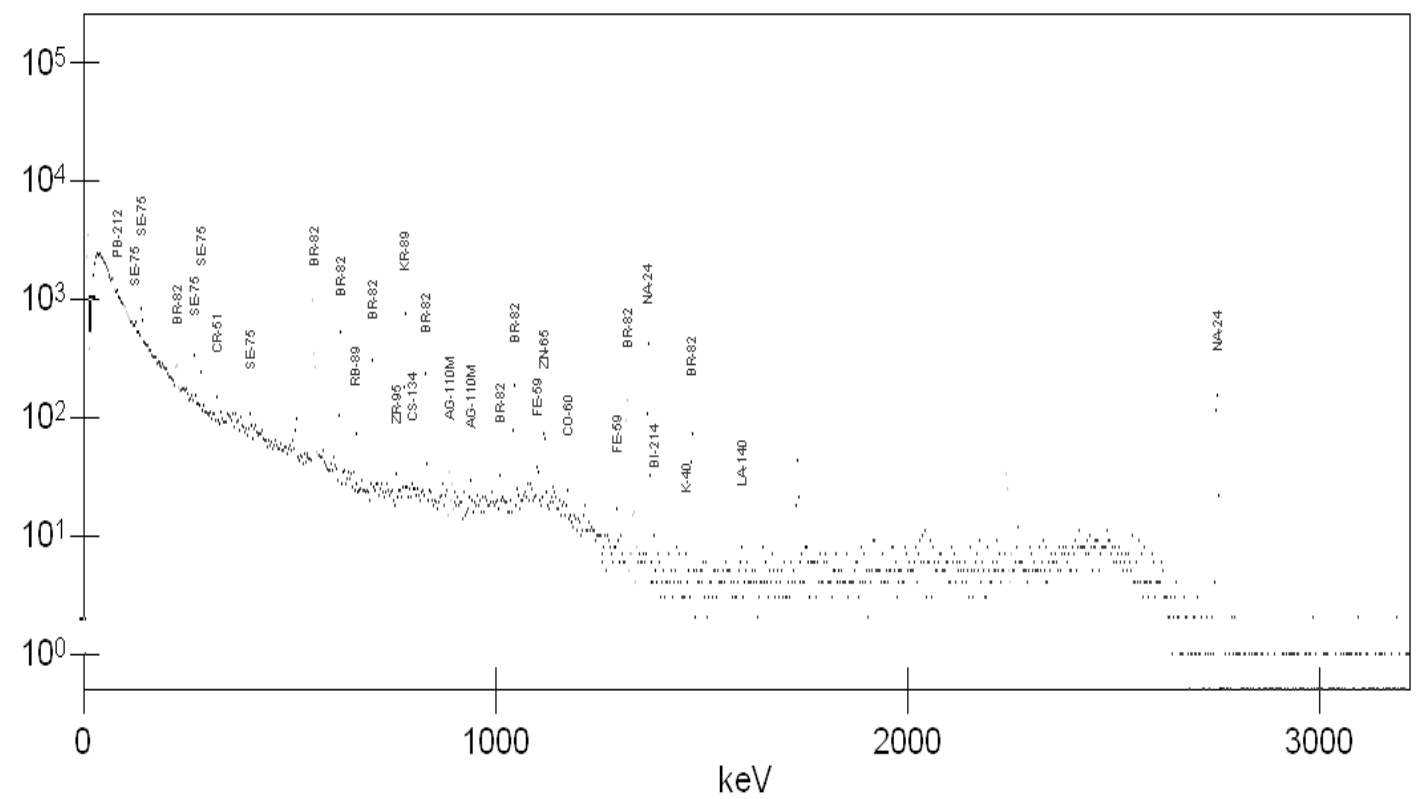

Gambar 1. Profil spektrum-y cuplikan bahan pangan (ikan tongkol) hasil iradiasi tanggal 2 Desember 2008, di RS3 RSG-GAS, $T_{\text {iradiasi }}=1$ jam, $t_{\text {decay }}=10$ hari, $t_{\text {pencacanan }}=1$ jam.

Hasil analisis cuplikan bahan pangan ditunjukkan pada Gambar 2 - 6. Pada gambar tersebut ditunjukkan hasil analisis unsur esensial dan toksik dalam cuplikan kacang-kacangan, sayuran, ikan, daging, telur, bumbu penyedap masakan, dan bahan pangan sumber karbohidrat.

Cuplikan bahan pangan yang dianalisis merupakan jenis bahan pangan yang biasa dikonsumsi. Hasil analisis menunjukkan bahwa secara keseluruhan cuplikan mengandung unsur-unsur esensial makro yaitu $\mathrm{K}, \mathrm{Cl}$, $\mathrm{Ca}, \mathrm{Na}$ dan $\mathrm{Mg}$. Unsur mikro seperti $\mathrm{Fe}, \mathrm{Zn}, \mathrm{Mn}$, dan Se serta unsur mikro esensial lainnya yang dalam jumlah tertentu bersifat toksik seperti As, $\mathrm{Cr}, \mathrm{Co}, \mathrm{Se}, \mathrm{Sb}$ dan unsur toksik $\mathrm{Hg}$.

Dirjen Pengawasan Obat dan Makanan, melalui Surat Keputusan (SK) POM No: 03725/B/SK/VII/89 memberikan batas maksimum cemaran logam dalam makanan. Dalam sebagian lampiran SK tersebut (Tabel 3) diatur batas maksimum untuk cemaran logam $\mathrm{As}, \mathrm{Pb}, \mathrm{Cu}, \mathrm{Zn}, \mathrm{Sn}$ dan $\mathrm{Hg}$ di dalam beberapa komoditi pangan. Hal ini tentunya berkaitan dengan efek cemaran logam-logam tersebut yang dapat membahayakan kesehatan manusia.

Tabel 3. Batas Maksimum Cemaran Logam dalam Makanan (Lampiran SK Dirjen POM no: 03725/B/SK/VII/89 [6]

\begin{tabular}{|c|c|c|c|c|c|c|c|c|}
\hline No & Komoditi & $\begin{array}{c}\text { As } \\
(\mathrm{mg} / \mathrm{kg})\end{array}$ & $\begin{array}{c}\mathrm{Pb} \\
(\mathrm{mg} / \mathrm{kg})\end{array}$ & $\begin{array}{c}\mathrm{Cu} \\
(\mathrm{mg} / \mathrm{kg})\end{array}$ & $\begin{array}{c}\mathrm{Zn} \\
(\mathrm{mg} / \mathrm{kg})\end{array}$ & $\begin{array}{c}\text { Sn } \\
(\mathrm{mg} / \mathrm{kg})\end{array}$ & $\begin{array}{c}\mathrm{Hg} \\
(\mathrm{mg} / \mathrm{kg})\end{array}$ & Keterangan \\
\hline 1 & $\begin{array}{l}\text { Tomat dan hasil } \\
\text { hasil olahannya }\end{array}$ & 1,0 & 1,0 & 50,0 & 40,0 & $40,0\left(250^{*}\right)$ & 0,03 & $\begin{array}{l}\text { Dihitung terhadap } \\
\text { makanan siap } \\
\text { dikonsumsi }\end{array}$ \\
\hline 2. & $\begin{array}{l}\text { Daging dan hasil } \\
\text { olahannya }\end{array}$ & 1,0 & 2,0 & 20,0 & 40,0 & $40,0\left(250^{*}\right)$ & 0,03 & \\
\hline 3. & $\begin{array}{l}\text { Ikan dan hasil } \\
\text { olahannya }\end{array}$ & 1,0 & 2,0 & 20,0 & 100,0 & $40,0\left(250^{*}\right)$ & 0,5 & $\begin{array}{l}\text { Dihitung terhadap } \\
\text { bahan kering }\end{array}$ \\
\hline
\end{tabular}


Analisis Unsur Toksik dan Makro-Mikro Nutrien Dalam Bahan Makanan Dengan Metode Analisis Aktivasi Neutron (Th. Rina Mulyaningsih, dkk..)

\begin{tabular}{|c|l|c|c|c|c|c|c|c|}
\hline No & \multicolumn{1}{|c|}{ Komoditi } & $\begin{array}{c}\text { As } \\
(\mathbf{m g} / \mathbf{k g})\end{array}$ & $\begin{array}{c}\mathrm{Pb} \\
(\mathbf{m g} / \mathbf{k g})\end{array}$ & $\begin{array}{c}\mathbf{C u} \\
(\mathbf{m g} / \mathbf{k g})\end{array}$ & $\begin{array}{c}\mathbf{Z n} \\
(\mathbf{m g} / \mathbf{k g})\end{array}$ & $\begin{array}{c}\mathbf{S n} \\
(\mathbf{m g} / \mathbf{k g})\end{array}$ & $\begin{array}{c}\mathrm{Hg} \\
(\mathbf{m g} / \mathbf{k g})\end{array}$ & Keterangan \\
\hline 4. & $\begin{array}{l}\text { Rempah-rempah } \\
\text { dan bumbu }\end{array}$ & 0,1 & 10,0 & 30,0 & - & - & - & \\
5. & $\begin{array}{l}\text { Sayuran dan hasil } \\
\text { olahannya }\end{array}$ & 1,0 & 2,0 & 5,0 & 40,0 & $40,0\left(250^{\star}\right)$ & 0,03 & \\
6. & $\begin{array}{l}\text { Tepung dan hasil } \\
\text { olahannya }\end{array}$ & 0,5 & 1,0 & 10,0 & 40,0 & - & 0,05 & \\
\hline
\end{tabular}

*) untuk produk yang dikemas dalam kaleng

Dengan mengacu Tabel 3, hasil penelitian menunjukkan bahwa konsentrasi $\mathrm{Zn}$ dalam kacang hijau sudah melebihi nilai batas (40 mg/kg), yaitu 45,15 $\pm 2,35 \mathrm{mg} / \mathrm{kg}$ sedangkan pada cuplikan jenis kacang-kacangan lainnya kadar Zn berkisar $35 \mathrm{mg} / \mathrm{kg}$. Demikian juga dengan konsentrasi Zn dalam sayur seledri, brokoli, tepung terigu, kemiri, lada, daging sapi dan daging kambing diatas nilai baku mutu. Tetapi batasan angka ini untuk unsur $\mathrm{Zn}$ juga perlu dipertimbangkan, mengingat fungsi $\mathrm{Zn}$ bagi pertumbuhan dan efeknya bila terjadi kekurangan dapat mengganggu pertumbuhan, penurunan imunitas dan gangguan metabolisme tubuh. $\mathrm{Zn}$ merupakan unsur mikro esensial yang dibutuhan kurang dari $100 \mathrm{mg} / \mathrm{hari}$. Angka kecukupan harian yang direkomendasikanan tergantung usia, jenis kelamin, dan kondisi tubuh adalah $15-19 \mathrm{mg}^{[1]}$. Dari beberapa penelitian rata-rata asupan harian belum mencapai angka yang direkomendasikan, yaitu baru $8,6 \mathrm{mg} / \mathrm{har} \mathrm{i}^{\left[{ }^{7]}\right.}$. Sehingga untuk mencapai angka yang direkomendasikan, maka jenis makanan yang dikonsumsi harus memiliki kadar Zn yang cukup tinggi seperti pada daging kambing dan sapi $\sim 300 \mathrm{mg} / \mathrm{kg}$, sayur brokoli $\sim 100 \mathrm{mg} / \mathrm{kg}$ dan nilai ini telah melebihi batasan baku mutu.

Berikut ini dijelaskan unsur-unsur makro esensial yang terkandung dalam cuplikan yang diteliti dan jumlah yang dibutuhkan tubuh serta efeknya bila terjadi kekurangan atau kelebihan.

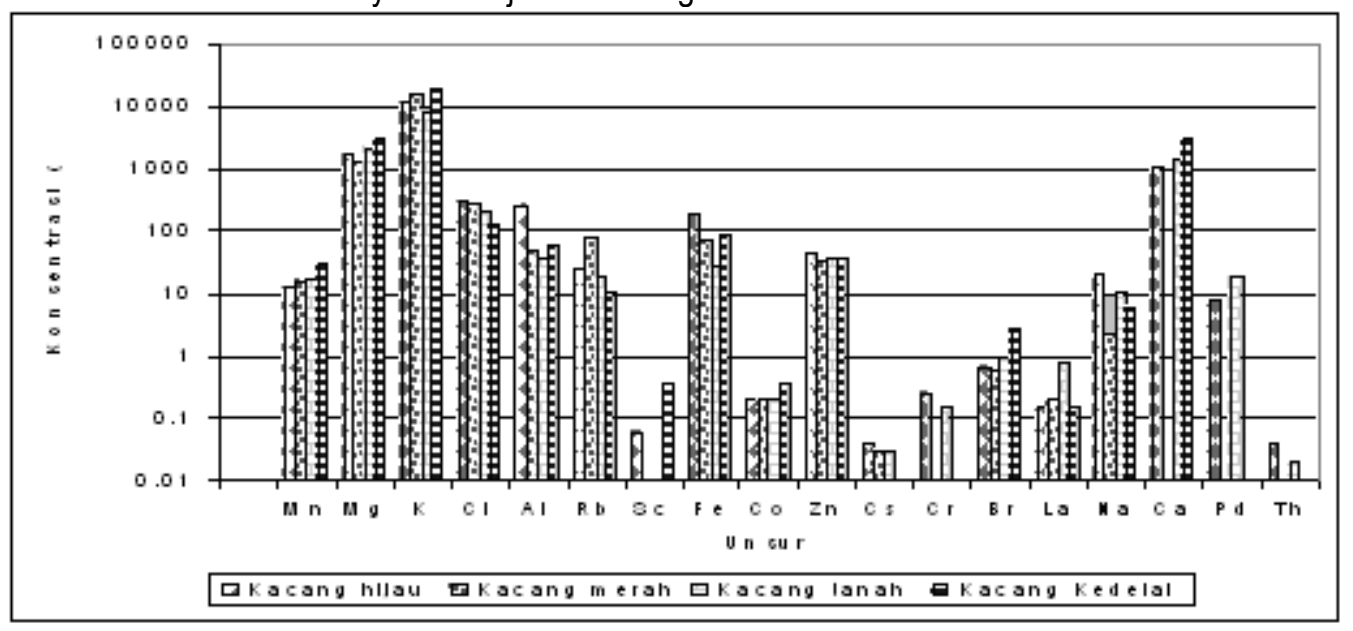

Gambar 2. Hasil analisis unsur dalam cuplikan kacang-kacangan

\section{Kalium (K)}

Hampir dalam semua jenis cuplikan yang diteliti memiliki kadar K cukup tinggi antara $2000 \mathrm{mg} / \mathrm{kg}-18,000$ $\mathrm{mg} / \mathrm{kg}$, kecuali pada cuplikan tepung (sumber karbohidrat) kisaran nilai antara $700-1700 \mathrm{mg} / \mathrm{kg}$. Jumlah harian yang direkomendasikan atau RDA (Recommended daily acceptable) adalah $3500 \mathrm{mg}$, umumnya asupan perhari $2500 \mathrm{mg}^{[7]}$. Dengan pengaturan makanan yang baik, kebutuhan $\mathrm{K}$ dapat tercukupi.

Kalium dimanfaatkan oleh sistem syaraf otonom untuk mengontrol detak jantung, fungsi otak, dan proses fisiologi penting lainnya. Kekurangan $\mathrm{K}$ dalam tubuh mengakibatkan kelelahan, gangguan keseimbangan cairan dalam tubuh dan gangguan dalam proses sintesis protein dalam makanan. Kelebihan $\mathrm{K}$ akan menimbulkan efek samping seperti gangguan perut, dan serangan jantung ${ }^{[7]}$. 


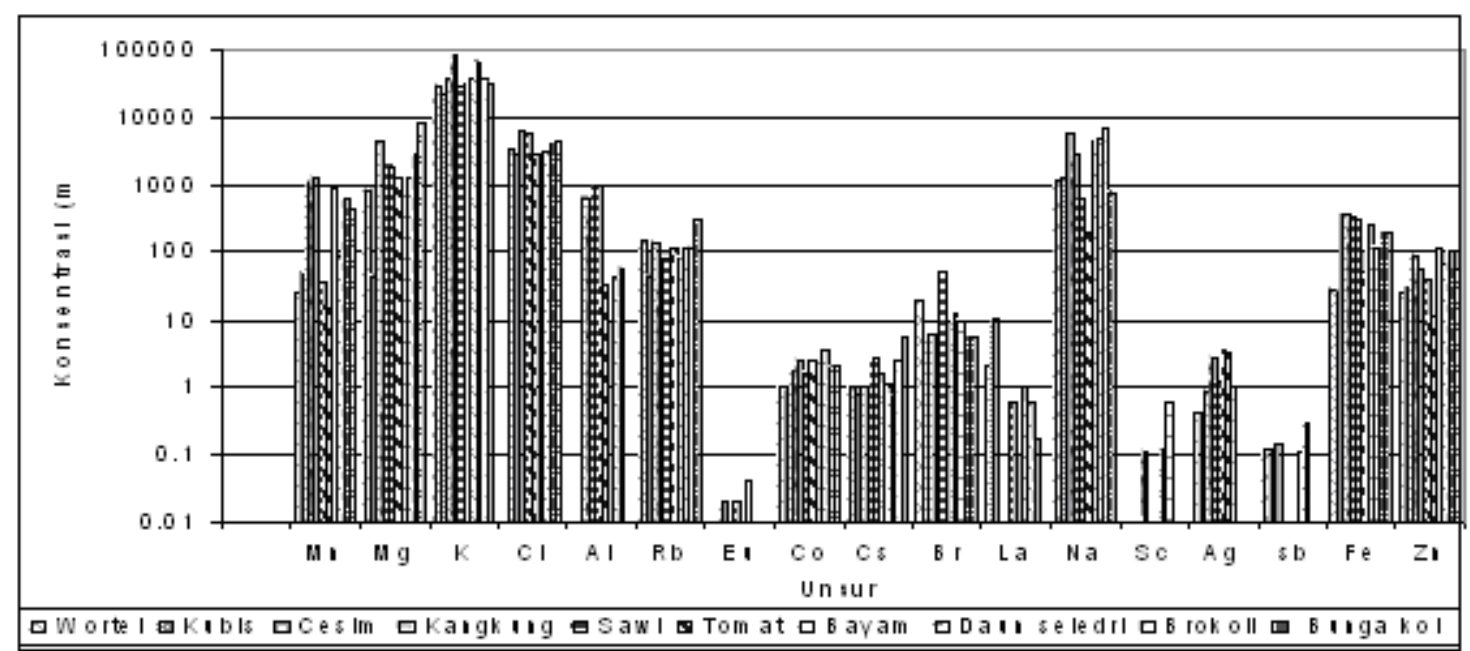

Gambar 3. Hasil analisis unsur dalam cuplikan sayuran

\section{Chlor (Cl)}

Kadar $\mathrm{Cl}$ dalam cuplikan memiliki nilai kisaran antara $102-6511 \mathrm{mg} / \mathrm{kg}$, Jenis bahan makanan dengan kadar $\mathrm{Cl}$ relatif tinggi terdapat pada sayuran yaitu antara $2750-6511 \mathrm{mg} / \mathrm{kg}$ dan tertinggi pada sayur kangkung, sedang pada beras kadarnya cukup kecil dan tidak ditemukan pada tepung terigu dan maizena. Asupan yang direkomendasikan tergantung usia, misalnya untuk usia 18 tahun ke atas 1,8 -5,1 g/hari ${ }^{[8]}$. Kekurangan $\mathrm{Cl}$ akan mengganggu pertumbuhan dan metabolisme dan kelebihan $\mathrm{Cl}$ menyebabkan hipertensi, edema dan kanker.

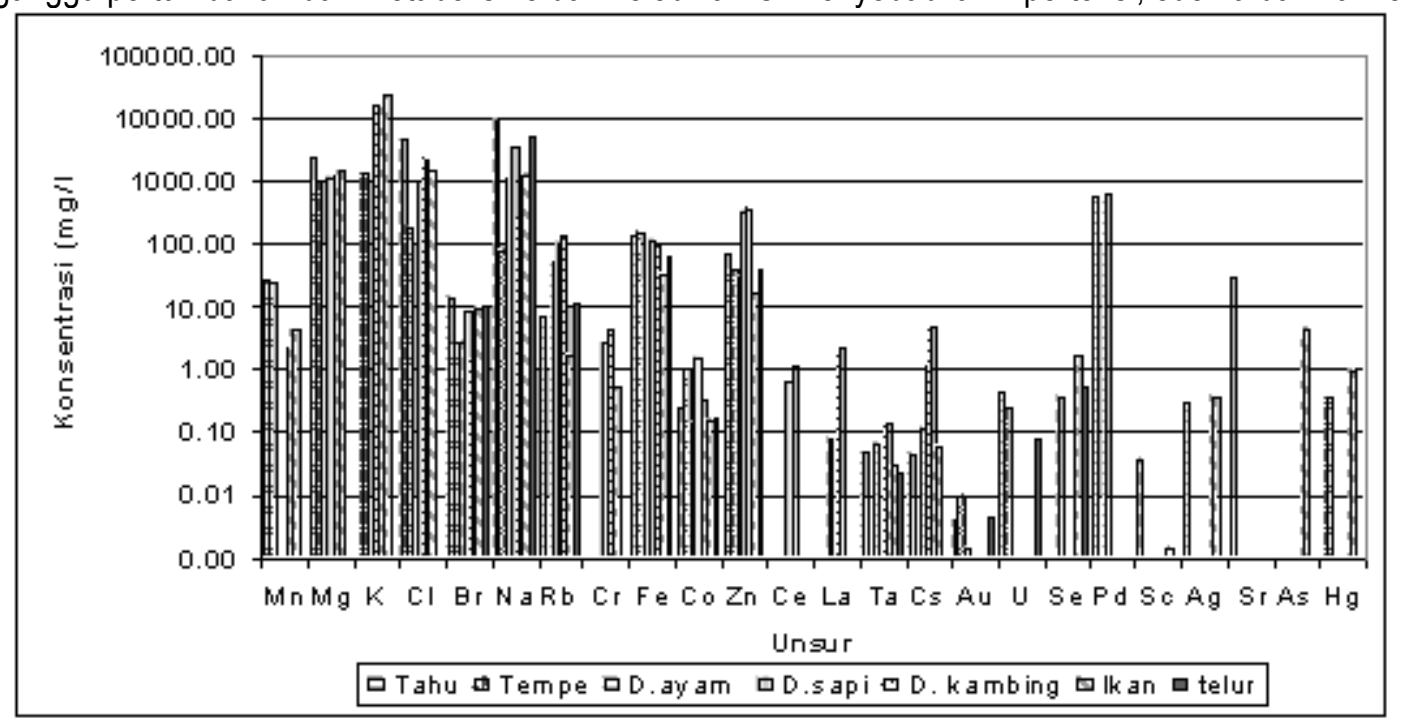

Gambar 4. Hasil analisis unsur dalam cuplikan bahan lauk pauk 


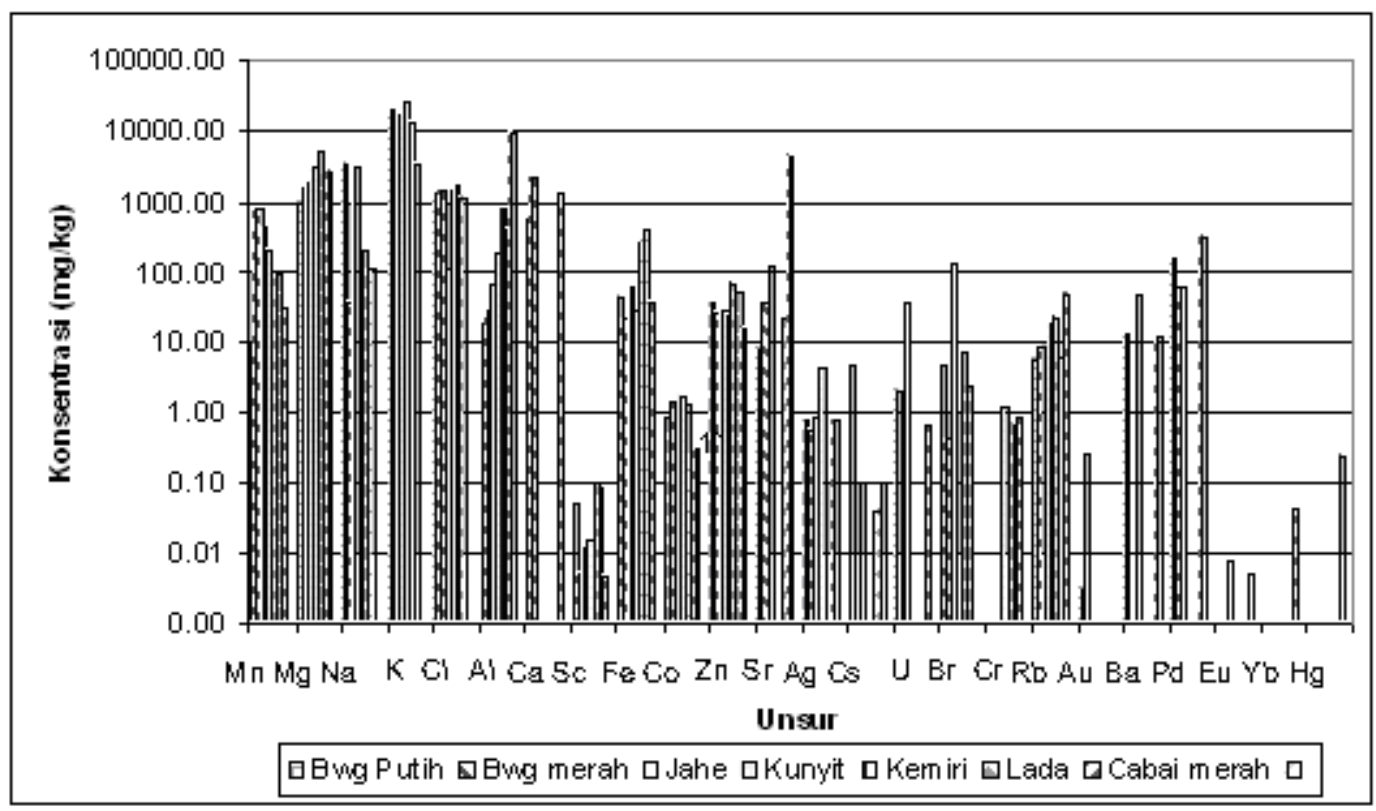

Gambar 5. Hasil analisis unsur dalam cuplikan bumbu dapur

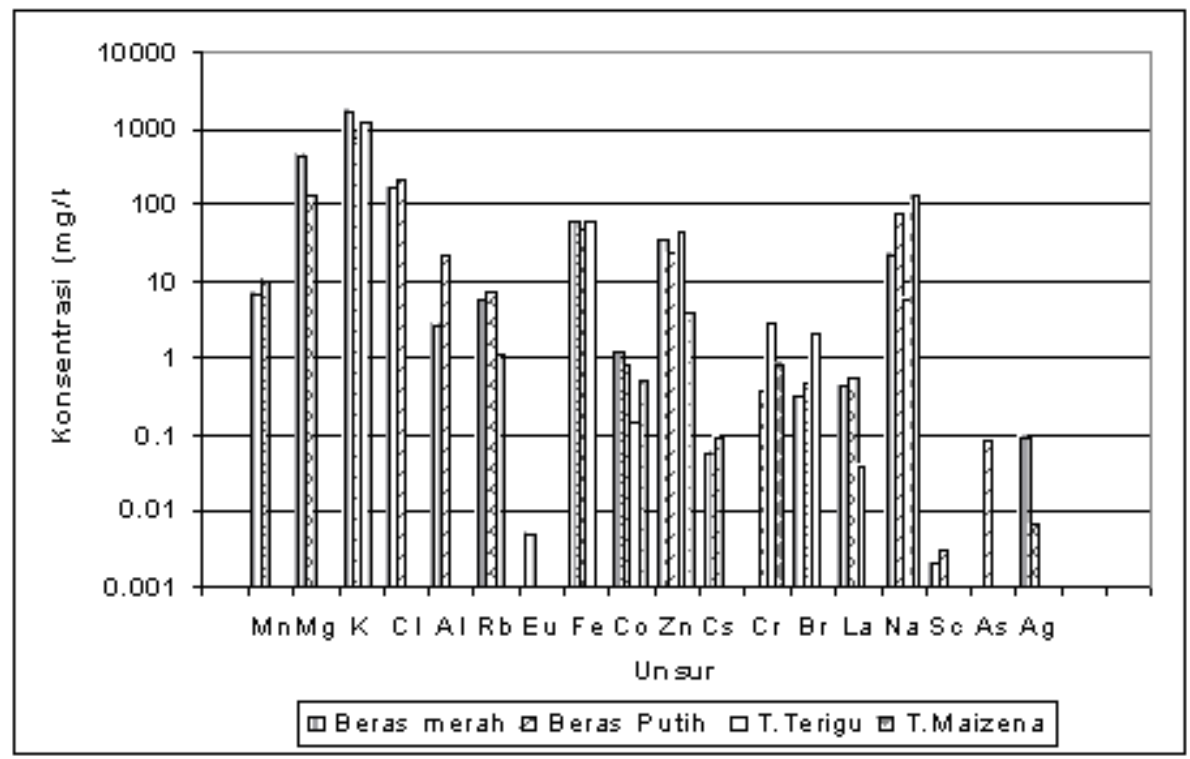

Gambar 6. Hasil analisis unsur dalam cuplikan tepung sumber karbohidrat

\section{Sodium (Na)}

Sayuran mengandung natrium cukup tinggi yaitu antara $1200-7047 \mathrm{mg} / \mathrm{kg}$. Begitu juga dengan $\mathrm{Na}$ di dalam cuplikan sumber protein (daging, ikan, telur dan tahu) yaitu hingga $9392 \mathrm{mg} / \mathrm{kg}$. Beras dan tepung terigu mengandung $\mathrm{Na}<100 \mathrm{mg} / \mathrm{kg}$, demikian juga dengan $\mathrm{Na}$ di dalam cuplikan kacang-kacangan $<20 \mathrm{mg} / \mathrm{kg}$. Jumlah harian yang direkomendasikan tidak lebih dari $500 \mathrm{mg} / \mathrm{har} \mathrm{i}^{[9]}$. Sebagian besar orang asupan akan $\mathrm{Na}$ lebih tinggi dari nilai tersebut. Biasanya kekurangan $\mathrm{Na}$ terjadi bukan karena asupan dari makanan atau minuman yang rendah tetapi terjadi karena gangguan kesehatan lainnya seperti diare. Asupan Na yang berlebihan harus diperhatikan karena dapat mengganggu kerja ginjal dan meningkatkan tekanan darah.

\section{Kalsium (Ca)}

Angka kecukupan harian yang direkomendasikan $800-1500 \mathrm{mg}$ untuk usia 18 tahun ke atas ${ }^{[7]}$. Kalsium berperan dalam proses metabolisme dan pembentukan tulang dan gigi (kira-kira $90 \%$ kalsium terdapat pada 
tulang dan gigi). Kadar Ca dalam cuplikan kacang-kacangan $>1000 \mathrm{mg} / \mathrm{kg}$. Pada cuplikan lainnya Ca tidak ditampilkan karena hasil analisis memiliki nilai ketidakpastian terlalu besar yaitu $>10 \%$, jadi tidak berarti bahwa dalam cuplikan tidak mengandung $\mathrm{Ca}$. Kekurangan $\mathrm{Ca}$ diantaranya dapat menyebabkan osteoporosis, depresi dan insomia, sedang kelebihan Ca menyebabkan gangguan jantung, tekanan darah tinggi dan glukoma ${ }^{[8]}$.

\section{Magnesium (Mg)}

Magnesium merupakan kation yang jumlahnya cukup banyak $(21-28 \mathrm{~g})$ didalam tubuh ${ }^{[6]}$. $60 \%$-nya ditemukan di dalam tulang, $1 \%$ di luar cell dan sisanya di dalam cell.

Magnesium (Mg) di dalam bahan makanan yang diteliti memiliki kisaran nilai antara $44-5105 \mathrm{mg} / \mathrm{kg}$, yaitu konsentrasi terendah terdapat pada kol dan tertinggi terdapat pada bumbu kemiri. Unsur ini terkandung cukup tinggi di dalam cuplikan kacang-kacangan $>1000 \mathrm{mg} / \mathrm{kg}$. Jumlah asupan magnesium setiap hari yang direkomendasikan berbeda tergantung jenis kelamin dan periode usia. Anak- anak membutuhkan asupan magnesium sekitar $250 \mathrm{mg} / \mathrm{hari}$, laki-laki dewasa $200-300 \mathrm{mg} / \mathrm{hari}$ dan wanita $300 \mathrm{mg} / \mathrm{hari}^{[10]}$. Mineral ini berperan dalam reaksi biokimia lebih dari 300 jenis enzim agar metabolisme berjalan dengan baik, dan berfungsi menjaga kekebalan tubuh.

Selain unsur makro esensial, didalam bahan makanan juga mengandung unsur mikro esensial yang dibutuhkan tubuh dalam jumlah kecil < $100 \mathrm{mg} /$ hari, seperti besi (Fe), seng (Zn), mangan (Mn), selenium (Se). Unsur mikro esensial lainnya seperti arsen (As), chrom (Cr), dan cobalt (Co), dibutuhkan dalam jumlah sangat kecil, dan apabila dikonsumsi dalam jumlah banyak akan memberikan efek negatif ${ }^{[8]}$.

\section{Besi (Fe)}

Angka kecukupan harian yang direkomendasikan adalah $15 \mathrm{mg}^{[7]}$. Kekurangan asupan mineral ini banyak diderita oleh golongan usia tertentu (pertumbuhan dan ibu hamil) karena asupan Fe yang tidak mencukupi, sehingga terjadi anemia. Dari hasil pengukuran dapat diketahui bahwa kandungan Fe dalam bahan makanan yang diteliti memiliki kisaran antara 27 - $400 \mathrm{mg} / \mathrm{kg}$ tergantung jenisnya. Hal ini dapat digunakan sebagai acuan perencanaan bahan makanan yang akan dikonsumsi, sehingga asupan Fe tidak di bawah nilai yang dibutuhkan.

\section{Mangan (Mn)}

Angka kecukupan harian yang direkomendasikan adalah $4-10 \mathrm{mg}$, untuk usia 18 tahun ke atas ${ }^{[8]}$. Unsur ini dibutuhkan untuk pertumbuhan tulang, juga memiliki peranan penting dalam proses metabolisme. $\mathrm{Mn}$ terkandung cukup tinggi pada cuplikan bumbu seperti kunyit, jahe dan bawang merah yaitu $>100 \mathrm{mg} / \mathrm{kg}$ dan pada beberapa jenis sayur seperti cesim, kangkung, bayam, brokoli dan bunga kol, sedangkan pada tepung, kacang dan cuplikan sumber protein < $30 \mathrm{mg} / \mathrm{kg}$. Kekurangan unsur ini memberi efek diantaranya depresi, hipoglikemia dan sakit kepala. Kelebihan Mn juga memberi efek seperti tremor, gangguan kejiwaan dan sakit kepala.

\section{Air Raksa (Hg)}

$\mathrm{Hg}$ terdeteksi di dalam cuplikan ikan dan cabai merah. Berdasarkan batasan yang tertera dalam Tabel 3 , apabila cabai merah dimasukkan dalam kelompok rempah-rempah dan bumbu, mestinya tidak boleh mengandung $\mathrm{Hg}$, tetapi apabila dimasukkan dalam kelompok sayuran dan hasil olahan, maka $\mathrm{Hg}$ maksimum yang diijinkan adalah $0,03 \mathrm{mg} / \mathrm{kg}$. Kandungan $\mathrm{Hg}$ dalam cabai merah adalah $0,23 \pm 0,01 \mathrm{mg} / \mathrm{kg}$, dan nilai ini sudah melewati baku mutu. $\mathrm{Hg}$ dalam cuplikan cabai merah kemungkinan berasal dari lingkungan (tanah) tempat tumbuhan ditanam. Selain itu $\mathrm{Hg}$ juga terdeteksi dalam cuplikan ikan 0,99 $\pm 0,01 \mathrm{mg} / \mathrm{kg}$, dan nilai ini juga sudah melebihi baku mutu yaitu $0,5 \mathrm{mg} / \mathrm{kg}$. Keberadaan $\mathrm{Hg}$ ini perlu diwaspadai karena sifatnya yang toksik bagi makhluk hidup. Hg dalam cuplikan ikan kemungkinan berasal dari perairan yang telah tercemar logam $\mathrm{Hg}$.

\section{Aluminium (Al)}

Al tidak termasuk unsur mikroesensial yang dibutuhkan oleh tubuh, Al merupakan unsur logam ringan yang banyak mencemari bahan makanan atau minuman, hal ini berkaitan dengan prosesing makanan (pengalengan, pemasakan dengan wadah yang terbuat dari Al). Kadar Al dalam cuplikan sayuran, bumbu, kacang-kacangan dan tepung, memiliki kisaran dari 2,7 mg/kg - $1042 \mathrm{mg} / \mathrm{kg}$, konsentrasi terendah ditemukan dalam beras merah dan tertinggi dalam sawi. Keberadaan Al dalam cuplikan ini kemungkinan berasal dari lingkungan (tanah/air) di 
mana bahan makanan itu ditanam. Tingginya asupan Al dalam jangka panjang dapat menyebabkan penyakit Alzheimers $^{[7]}$.

\section{Arsen (As), selenium (Se), chrom ( $\mathrm{Cr}$ ), cobalt (Co) dan antimon (Sb)}

Peranan As didalam tubuh belum diketahui. Toksitas As tergantung pada valensinya dan dalam campuran organik atau inorganik. Dosis lethal (mematikan) As inorganik antara $120-200 \mathrm{mg}^{[7]}$. Dari hasil analisis terdeteksi bahwa ikan dan beras mengandung logam As, yaitu masing-masing 4,28 $\pm 0,02 \mathrm{mg} / \mathrm{kg}$ dan 0,08 \pm $0,001 \mathrm{mg} / \mathrm{kg}$. Berdasarkan Tabel 3, konsentrasi As dalam tepung dan hasil olahan maksimum 0,05 mg/kg dan dalam ikan dan hasil olahan maksimum $0,5 \mathrm{mg} / \mathrm{kg}$. Jadi As dalam cuplikan beras dan ikan laut sudah melebihi baku mutu yang dipersyaratkan. Hal ini perlu diperhatikan mengingat logam ini bersifat toksik.

Se merupakan unsur kofaktor dari enzim antioksidan. Angka kecukupan harian yang direkomendasikan adalah $70 \mu g^{[8]}$. Se hanya terdeteksi pada cuplikan ikan dan daging ayam. Kekurangan Se biasanya ditambahkan dengan mengkonsumsi suplemen.

$\mathrm{Cr}$ termasuk unsur yang bersifat toksik, terdeteksi pada beberapa jenis cuplikan dengan kisaran konsentrasi terendah $0,15 \pm 0,01 \mathrm{mg} / \mathrm{kg}$ pada kacang tanah dan tertinggi 4,22 $\pm 0,09 \mathrm{mg} / \mathrm{kg}$ pada daging kambing. Kebutuhan tubuh akan $\mathrm{Cr}$ diperkirakan antara 50 - $200 \mu \mathrm{g}$ per hari ${ }^{[8]}$. Kekurangan $\mathrm{Cr}$ akan menyebabkan insulin kurang efektif, dan kelebihan menyebabkan penurunan imunitas dan pembengkakan limpa.

Unsur Co bersifat toksik sedang, termasuk unsur esensial yang merupakan pembentuk vitamin B12. Terdeteksi hampir pada setiap jenis cuplikan dengan kisaran nilai antara $0,15-3,53 \mathrm{mg} / \mathrm{kg}$. Jumlah asupan harian yang direkomendasikan adalah $10-20 \mu \mathrm{g}^{[8]}$.

$\mathrm{Sb}$ juga termasuk unsur toksik yang teridentifikasi dalam cuplikan sayur wortel, cesim, bayam dan daun seledri, dengan konsentrasi $\sim 0,1 \mathrm{mg} / \mathrm{kg}$. Sb termasuk unsur karsinogenik walaupun sifatnya kurang toksik dibandingkan $A s^{[7]}$.

Dalam beberapa cuplikan juga menggandung unsur lainnya seperti $\mathrm{Rb}$ yang dibutuhkan dalam jumlah kecil untuk pertumbuhan; kadar Rb antara $30-300 \mathrm{mg} / \mathrm{kg}$ ditemukan dalam sayuran, sedangkan dalam tepung $<10$ $\mathrm{mg} / \mathrm{kg}$. Skandium (Sc) tidak termasuk unsur toksik tapi karsinogenik. Sc dalam cuplikan ditemukan $<0,1 \mathrm{mg} / \mathrm{kg}$. Sc ini kemungkinan berasal dari lingkungan yang telah tercemar. Lantanum (La) tidak terkuantifikasi dalam semua jenis cuplikan, kadarnya antara $0,5-10 \mathrm{mg} / \mathrm{kg}$. Unsur ini bila terakumulasi dalam tubuh dapat memberi efek negatif terhadap sistem repreduksi dan sistem syaraf ${ }^{[8]}$. Brom (br), kebutuhan hariannya belum didefinisikan, tetapi diperkirakan kebutuhan harian dari makanan dan minuman 1- $3 \mathrm{mg} / \mathrm{hari}{ }^{\left[{ }^{[8]}\right.}$. Kekurangan $\mathrm{Br}$ menyebabkan hipertiroid dan insomia, sedangkan apabila kelebihan memberi efek negatif, diantaranya halusinasi dan penurunan memori.

Dari penelitian ini dapat diketahui konsentrasi unsur makro dan mikro esensial yang terkandung dalam cuplikan bahan makanan. Informasi ini sangat penting untuk memperkirakan pengaturan diet yang sehat, sehingga kebutuhan tubuh akan unsur-unsur esensial tercukupi. Di samping itu, terdeteksinya unsur-unsur As dan $\mathrm{Hg}$ dalam beberapa jenis cuplikan bahan pangan dengan nilai konsentrasi yang telah melebihi baku mutu perlu mendapat perhatian, karena efeknya terhadap kesehatan.

\section{KESIMPULAN}

Dari penelitian dapat disimpulkan bahwa, cuplikan bahan pangan mengandung makro nutrien : $\mathrm{K}, \mathrm{Ca}, \mathrm{Mg}$, $\mathrm{Na}$ dan $\mathrm{Cl}$ yang memiliki kadar lebih dari $1000 \mathrm{mg} / \mathrm{kg}$, mikronutrien : $\mathrm{Fe}, \mathrm{Mn}, \mathrm{Zn}, \mathrm{Se}, \mathrm{Br}, \mathrm{Rb}$, dan La yang memiliki kadar antara 10 hingga kurang dari $1000 \mathrm{mg} / \mathrm{kg}$, dan mikro nutrien bersifat toksik bila asupan berlebihan: $\mathrm{Co}, \mathrm{Sb}$ dan $\mathrm{Cr}$ dengan kadar kurang dari $5 \mathrm{mg} / \mathrm{kg}$, serta unsur toksik lainnya $\mathrm{Hg}$, As dan Al.

Beberapa unsur toksik seperti $\mathrm{Hg}$ dalam cabai merah, dan ikan laut serta As dalam ikan dan beras sudah melebihi baku mutu. Hal ini perlu mendapat perhatian karena sifat toksik dari kedua unsur tersebut bagi kesehatan.

Kadar $\mathrm{Zn}$ dalam beberpa jenis cuplikan sudah melebihi baku mutu yang dijinkan. Tetapi batasan nilai tersebut perlu dipertimbangkan, mengingat rata-rata asupan harian akan $\mathrm{Zn}$ masih di bawah nilai yang 
direkomendasikan yaitu $15 \mathrm{mg} / \mathrm{hari}$, dan kekurangan unsur ini dapat mengganggu pertumbuhan dan metabolisme tubuh.

Kadar Al dalam bahan makanan cukup tinggi $(\mathrm{mg} / \mathrm{kg}) 500<\mathrm{Al}>10$, logam Al termasuk logam ringan yang bersifat toksik bagi tubuh, sehingga keberadaannya perlu mendapat perhatian.

Dengan mempertimbangkan angka kecukupan kebutuhan harian RDA, kandungan nutrien dalam berbagai jenis cuplikan bahan pangan dapat digunakan untuk memperkirakan diet sehat bagi tubuh.

\section{DAFTAR PUSTAKA}

1. DARMONO, "Logam dalam sistem Biologi Makhluk Hidup" Penerbit Universitas Indonesia, ISBN 979-456150-3, Desember (1994).

2. LUSIANA INDRIASARI, "Waspadai Bahan Kimia Lain dalam Makanan", Minggu, 15 Januari 2006, http://www,kompas, com/kesehatan/news/0601/15/113636,htm.

3. MUHAYATUN, NATALIA A, "Studi Pendahuluan Penentuan Kadar Beberapa Unsur Makro dan Mikro dalam Cuplikan Makanan", Proseding Seminar Sains dan Teknologi Nuklir, Bandung, (2007) 311-320.

4. TH. RINA M, RUKIHATI, ISTANTO, "Analisis Unsur Esensial Dalam Teh Komersial Indonesia dengan Metode AAN", Prosiding Seminar Nasional AAN 2008, Sabuga, ITB Bandung (2008) 109-118.

5. SUMARDJO, TH.RINA M, ISTANTO, SITI S, "Analisis Unsur Kelumit dalam Cuplikan Minuman Sachet dengan Metode AAN", Prosiding Seminar Nasional AAN 2008, Sabuga, ITB Bandung (2008) 127-134.

6. SELVINA PAYUNG, Analisa Logam Berat dalam Kubis yang dijual di Pasar Senen Jak Pus dengan Metode AAN, Tugas akhir Farmasi Untag 1945 Jakarta, 2005, hal 63-64.

7. Metals in health and disease, Metals in Nutrition, http://www.portofolio.mvm.ed.ac.uk/studentwebs/ session2/group29, diakses Januari 2009.

8. Acu-Cell Nutrition, http://www.acu-cell.com/br.html, diakses Januari 2009.

9. http://www.healingwithnutrition.com/mineral.htm, diakses Januari 2009.

10. Keistimewaan Magnesium, http://site.100percentnutrisyen.com/design/1065/index.asp?pageid=29166\& Accld=4465, diakses Mei 2009. 